\title{
保険薬局における在宅医療への実施状況と 薬剤師の意識・意見に関する調査研究
}

\author{
廣谷芳彦 ${ }^{* 1}$, 八十永理 ${ }^{1}$, 的場俊哉 ${ }^{2}$, 池田賢二 ${ }^{1}$, 恩田光子 ${ }^{2}$, 川瀬雅也 ${ }^{3}$, 名徳倫明 ${ }^{1}$ \\ 大阪大谷大学薬学部臨床薬剤学講座 ${ }^{1}$, 大阪薬科大学薬学部臨床実践薬学研究室 ${ }^{2}$ \\ 長浜バイオ大学バイオサイエンス学部
}

\section{A Research Survey on Implementation Situation of Home Medical Care, Pharmacists' Attitudes and Opinions in Community Pharmacies}

\author{
Yoshihiko Hirotani ${ }^{* 1}$, Eri Yaso ${ }^{1}$, Syunya Matoba ${ }^{2}$, Kenji Ikeda', Mitsuko Onda ${ }^{2}$, \\ Masaya Kawase $^{3}$ and Michiaki Myotoku ${ }^{1}$ \\ Laboratory of Clinical Pharmaceutics, Faculty of Pharmacy, Osaka Ohtani University ${ }^{\text {, }}$ \\ Clinical Laboratory of Practical Pharmacy, Osaka University of Pharmaceutical Sciences ${ }^{2}$, \\ Faculty of Bioscience, Nagahama Institute of Bio-Science and Technology ${ }^{3}$ \\ $\left[\begin{array}{l}\text { Received August 17, } 2011 \\ \text { Accepted March 16, } 2012\end{array}\right]$
}

To clarify the issues involved in the promotion of pharmacists' participation in home medical care, we performed a questionnaire survey on the implementation situation of home medical care and pharmacists' attitudes and opinions in community pharmacies. We mailed a questionnaire to 715 community pharmacies in July 2010. The pharmacists' attitudes and opinions were validated through text mining. $78.3 \%$ of community pharmacies were requested to visit a patient's home and provide a pharmaceutical service, but only $53.0 \%$ of these visits were made. In many pharmacies, an average of 2.3 pharmacists provided care to within 5 patients and visited the patient's homes twice a month. Meanwhile, $27.7 \%$ of the pharmacies delivered prescription medicines to nursing facilities, and of these, only $19.8 \%$ of the pharmacies provided instructions regarding pharmaceutical care. Only $9.1 \%$ of the pharmacists participated in training workshops related to home medical care. $48.4 \%$ of the pharmacists recognized that they had to provide pharmaceutical care visits for patients coming to their pharmacies. Only $3.7 \%$ of the pharmacists participated in joint directions at the time of hospital discharge. Results of text mining showed the need for pharmaceutical care visits for patients with poor compliance, those who found it difficult to go to the pharmacy or had dementia, and the elderly living alone. Also, the patients and other homecare staff felt the necessity for pharmacists to provide pharmaceutical care in the patient's home. In conclusion, in order to promote home medical care, inhibitory factors such as lack of pharmacists' manpower and cooperation with home care staff, and insufficient provision of training workshops for home medical care need to be tackled.

Key words — home medical care, community pharmacy, questionnaire survey, pharmaceutical care visits, cooperation

\section{緒言}

超高齢社会にある日本において，介護サービス を受ける高齢者の数は, 介護保険が創設された 2000 年の 149 万人から 2011 年には 327 万人と約 2.2 倍に増加した（http://www.mhlw.go.jp/toukei/ saikin/hw/kaigo/kyufu/2011/03.html). 患者が在宅
（居宅）で療養生活を営むには，本人や家族をは じめ医療, 福祉の関係職種の理解と協力が必要で あるが, 薬荗師も在宅医療への参画が強く望まれ ている ${ }^{1)}$. 特に, 地域薬局では, 薬局・薬剤師の 機能と専門性を活かして, 自宅や介護施設等で療 養している高齢者に対して適正な医薬品の供給お よび品質の確保, アドヒアランスの向上, 服薬管

\footnotetext{
*大阪府富田林市錦織北3-11-1
} 
理指導による医療安全の確保, 副作用の早期発見 など，在宅医療の質を向上させる役割を担うこと が求められている ${ }^{2}$ 。在宅医療に関する調用報酬 は手厚く評価されており，保険薬局がこれから取 り組むべき目標および業務として期待されてい る。しかし, 日本薬剤師会の調査では, 在宅患者 訪問薬剤管理指導の届出率は $63.9 \%$ あるが，実 際に訪問を実施したことのある保険薬局は $14.4 \%$ と非常に少ない（http://www.nichiyaku.or.jp/action/ wp-content/uploads/2011/04/kenshou.pdf).

今後, 薬局・薬郕師がチームの一員として在宅 医療へより積極的に参加することを可能にするた めには，保険薬局の在宅医療への参加状況，その 実施に必要な薬剂師業務研修会の開催そして他職 種連携の方法に関する現状把握が必要であると考 える。また，在宅医療の普及を阻害している要因 を明らかにするため，在宅医療に対する薬羭師の 意識を知る必要がある。そこで本研究では, 薬剤 師による在宅医療への実施状況の把握と促進条件 を探ることを目的として保険薬局を対象にアン ケートによる調査を実施した。

\section{方法}

調査方法および期間：平成 22 年 7 月大阪府下 3 地域の大阪府薬剤師会会員の保険薬局 715 施設を 対象に自記式調査票を配付し, 回答済み調査票は 郵送にて回収した。調査期間は平成 22 年 7 月の 1 カ月間とした.

調査対象：調查対象とした大阪府下 3 地域のう ち, 大阪北部は吹田市, 池田市および豊中市で送 付会員数 254, 南東部は松原市, 藤井寺市, 羽曳 野市, 富田林市とその近隣町村, 大阪狭山市そし て河内長野市で送付会員数 195, 南西部は堺市で 送付会員数 266 であった。

調査項目：調查票を図 1 に示す。調査項目は, 在 宅医療の実施状況を問う項目（訪問指導届出・経 験の有無, 退院時共同指導実施状況, 他職種連携 経験等）と在宅医療全般に対する保険薬局薬剂師 の意識を問う項目とした. 各調査項目について 3 地域間で差が見られるか否かを $\chi^{2}$ 検定により 行ったが,一部を除き（質問 5. (2) -b と質問 6. (1) ) 統計的有意差が見られなかったため，3 地区すべ

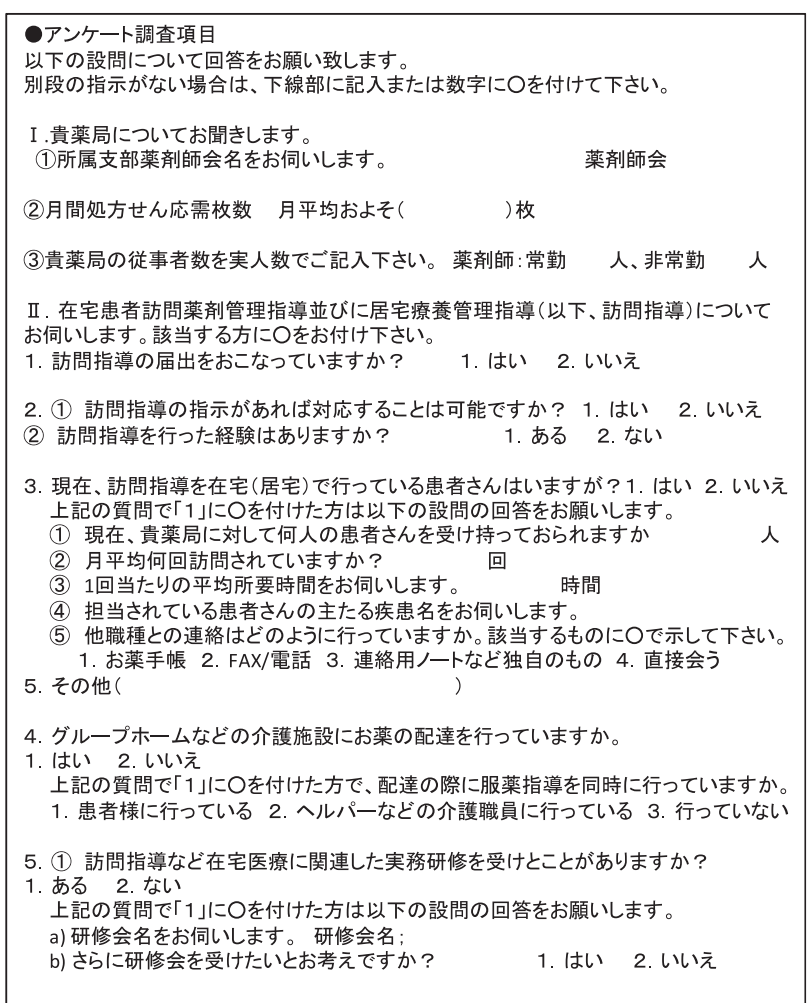

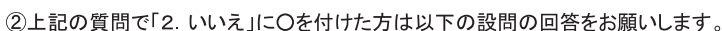
a) 研修会を受けなかった理由をお伺いします。

1. 訪問指導する時間がない

2. 訪問指導する薬剤師が足りない

3. 訪問指導する方法がわからない

4. 在宅医療に関心がない(訪問指導する意思がない)

5. 適切な研修会がない 6. その他(

b) 今後、在宅医療関連の研修会に参加したいですか。 1.はい 2.いいえ

6. (1)退院時共同指導を行っていますか。 1.はい 2. いいえ 上記の質問で「2」に○を付けた方は今後される計画はありますか。1.ある 2 . ない (2)退院時共同指導は在宅医療を円滑に進めるのに必要とお考えですか 1.はい2. いいえ 上記の質問で「 1 」に○を付けた方は以下の設問の回答をお願いします。 1. 病院と薬局における服薬指導が統一できるから 2. 患者の病態や検査值が把握できるから

3. その他(

上記(2)の質問で「2」に○を付けた方はその理由(このシステムの問題点)をお聞かせ下 さい。 理由:

7. チーム医療などで他職種間で話し合ったことはありますか? 1.はい 2 2. いいえ 上記の質問で「1」に○を付けた方は、具体的にどのように行われているかお伺いします。 回答:

8. 来局患者で訪問指導を行う必要性を感したたことはありますか。1.はい２. いいえ 上記の質問で「1」に○を付けた方は、その具体的にお伺いします。 回答:

9. 基準調剤加算1又は2を届出していますか (24時間対応)。 1 . はい $\quad 2$. いいえ 10. 訪問指導など在宅医療全般について、ご意見をお聞かせ下さい。

図 1 アンケート調査用紙 
ての保険薬局の回答結果の值を総計してその平均 值あるいはその割合（\%）を記載した。なお，回 答は無記名とし，保険薬局の個別情報が特定され ないように配慮した。

解析方法：在宅医療に対する薬剤師の意識につい ては，質問 8 と質問 10 での自由記述形式による 任意回答を用いたテキストマイニングを行い，内 容の視覚化・体系化を試みた。テキストマイニン グの解析過程は，(1)記述内容の分類 (2)記述文の 前处理 (3)記述文からのキーワードの抽出 (4)抽 出されたキーワードの“カテゴリ化”（5)カテゴ リ間の関倸性を把握するための “視覚化”の 5 つ の作業を行った．前処理では，同じ質問に対して 複数の回答者が異なる単語を使用している場合, 内容が同様であれば 1 つ単語に置き換える作業 を行った，抽出では，「感性分析」を行った。“カ テゴリ化”では, ほかの複合語に含まれているキー ワードを特定し，それらを1つの包括的なカテゴ リにまとめる内包と, 回答内で同時に頻繁に出現 し一連の回答内で強く関連しているキーワードに まとめる共起規則の手法を採用した. 視覚化では, 「web グラフ」を採用し，キーワードの度数頻度 およびリンク強度での関係性を示した。分析に はPASW Text Analysis For Survey 3.0.4J ( IBM 社製) を用いた。

\section{結果}

\section{1. 在宅医療への薬剤師の実施状況}

薬局の経営規模：715 中 375 の保険薬局から回答 を得た（回収率 $52.7 \%$ )。地区別の回答薬局数（回 収率）は, 大阪北部：129（48.9\%), 南東部： 113 （57.95）, 南西部：133（52.8\%）であった。 薬局規模を表す保険薬局の月間処方せん応需枚数 は, 月平均で 3 地区ともほぼ同数で 1208 枚であっ た（表 1)。また，常勤薬荗師数は 2.26 人，非常 勤薬剂師数は 2.22 人であった。 なお，これら 3 項目について 3 地区内の平均值に有意差は見られ なかった。

訪問指導届けと経験の有無：訪問指導の届出は 275 (73.3\%) の薬局で行っており，また，訪問 指導の指示があれば対応可能と回答した薬局もほ
ぼ同数の $282(75.4 \%)$ であったが, 訪問指導を

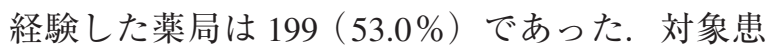
者の疾患は, 長期療養が必要な認知症, 高血圧症 そして後遺症を含む脳疾患が多く見られた（表 2).

訪問指導の実態: 現在, 訪問指導を行っている保 険薬局数は 114 (30.3\%) であった。 その内, 現 在 5 人以内の患者を担当している保険薬局が 63 $(55.2 \%)$, 月 2 回以内の頻度で訪問している保険 薬局は $66(57.9 \%)$, 訪問平均所要時間が 30 分以 内の保険薬局が $83(72.8 \%)$ で, それぞれ最も多 く占めていた（表 3)。他職種との連絡手段とし て電話 /FAXを使用している薬局は 195 中 95 (48.7\%) を占めていたがほかに, 直接面会（38 薬局；19.5\%), 拈薬手帳（35薬局；17.4\%）そ して連絡ノート（18 薬局；9.3\%）などが見られ た（表 3).

介護施設での薬剤師の関与 : 介護施設に処方薬を 配達している薬局数は $103(27.7 \%)$ で, その内 $79.9 \%$ の施設で服薬指導を行っていたが, 薬片師 が行っていた割合は $19.8 \%$ で，ほとんどの施設で は介護職員が服薬援助や薬剤管理を行っていた

表 1 アンケート回答薬局の処方せん枚数㧍よび薬 剂師数

\begin{tabular}{lcccc}
\hline \hline \multicolumn{1}{c}{ 質問項目 } & 北部 & 南東部 & 南西部 & $\begin{array}{c}3 \text { 地区 } \\
\text { 平均 }\end{array}$ \\
\hline 月平均処方せん枚数 & 1156 & 1183 & 1285 & 1208 \\
常勤薬剤師数 (名) & 2.20 & 2.21 & 2.37 & 2.26 \\
非常勤薬剤師数 (名) & 2.63 & 1.98 & 2.05 & 2.22 \\
\hline & & \multicolumn{4}{c}{ (回答者数 : 375) }
\end{tabular}

表 2 調査回答のあった在宅患者の疾患名

\begin{tabular}{lc}
\hline \hline \multicolumn{1}{c}{ 疾患名 } & 割合 $(\%)$ \\
\hline 認知症 & 18.0 \\
高血圧 & 14.3 \\
脳疾患 (後遺症) & 13.5 \\
がん & 8.3 \\
呼吸器疾患 & 8.3 \\
糖尿病 & 8.3 \\
心疾患 & 5.2 \\
腰痛・関節疾患 & 3.8 \\
パーキンソン病 & 3.0 \\
栄養障害 (PEG 患者) & 3.0 \\
その他 & 14.3 \\
\hline \multicolumn{2}{r}{}
\end{tabular}


表 3 保険薬局における訪問指導状況の実態
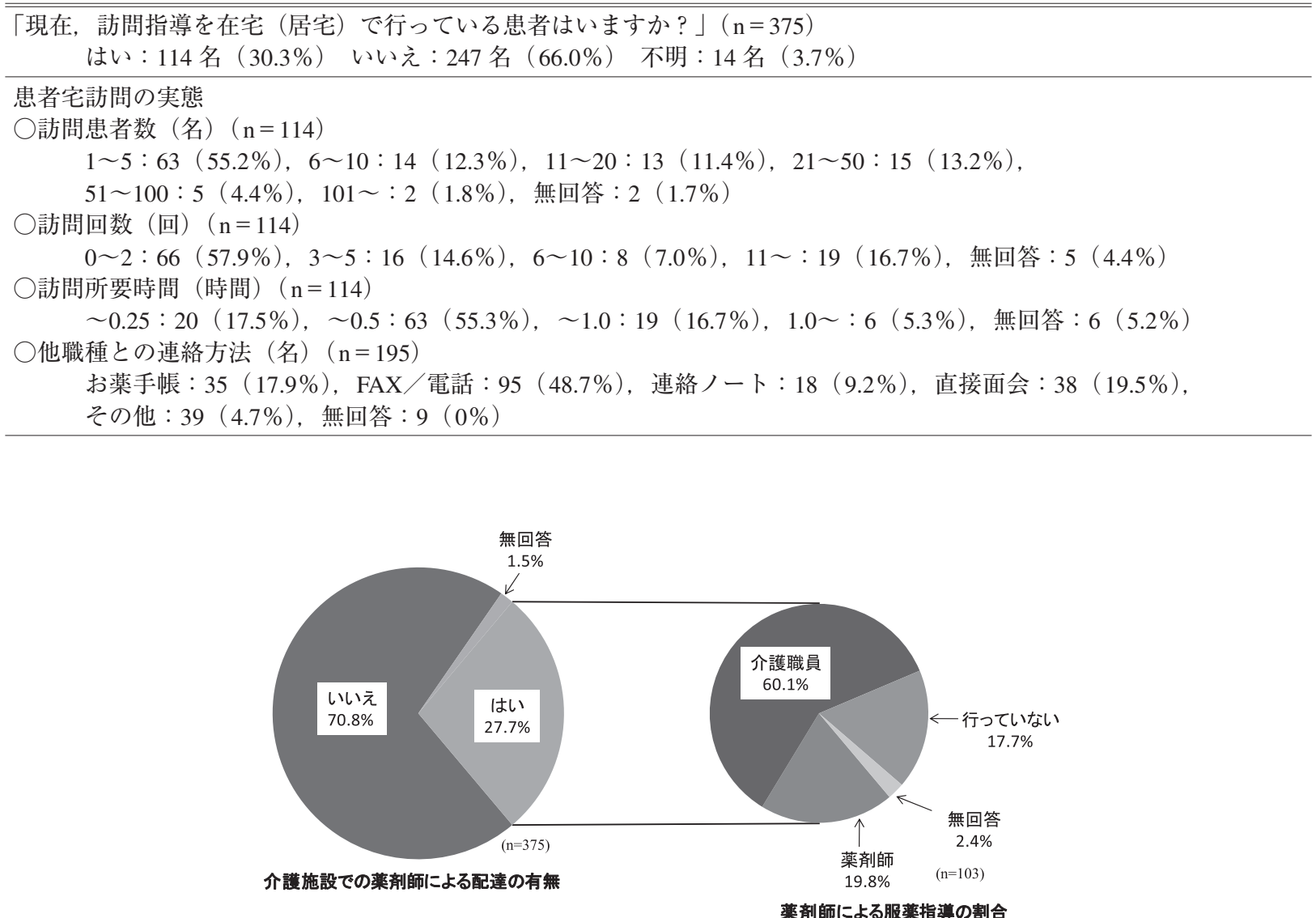

図 2 介護施設での薬剤師の関与状況

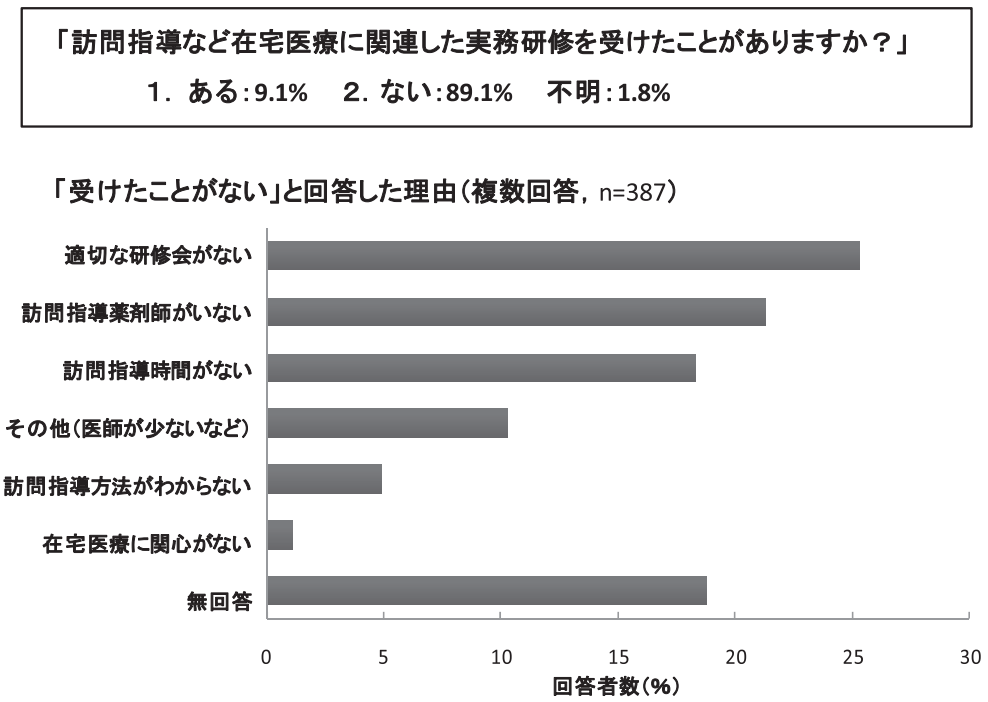

図 3 在宅医療に関連した実務研修を受けなかった理由

(図 2).

在宅関連研修会の参加状況：訪問指導方法などの 在宅関連の研修を受けた保険薬局の割合は 375 薬 局中 $34(9.1 \%)$ で，非常に少ないことが示され
た（図 3）。一方，「さらに研修会を受けたい」と 回答した保険薬局薬剂師は 76.1\%で, 研修会を受 ける意思があることが示された。研修会に参加し なかった理由として,「適切な研修会がない」が 
98 薬局 (25.3\%) で最も多く見られたが，「訪問 指導する方法がわからない」，「訪問指導する時間 がない」などの理由で訪問指導する条件が整って いないため研修会に参加しなかった現状が見られ た（図 3）。

退院時共同指導実施の有無：退院時共同指導を 行っている保険薬局は 375 薬局中 $13 （ 3.7 \%)$ で ほとんどの保険薬局で実施していなかった. また， 現在行っていないが，「今後行う計画があるか」 の問いに対し， $70.8 \% の$ 保険薬局が「いいえ」と 回答した。その理由として,「退院時間の調整が 困難」の記述が多く見られた。「チーム医療など で他職種間と話し合ったことがありますか」の問 いに対し 375 薬局中 $92(24.6 \%)$ の保険薬局があ ると回答し, その方法として担当者カンファレン スが $26.7 \%$ で最も多く, 次いで地域研修会 （12.5\%）や電話／FAX（8.3\%）が多く見られた.

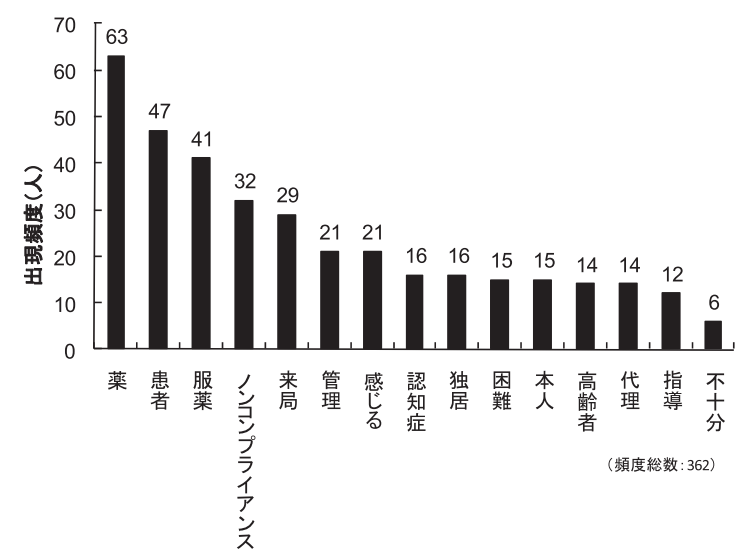

図 4 訪問指導の必要性に関するアンケート結果で の各カテゴリの出現頻度

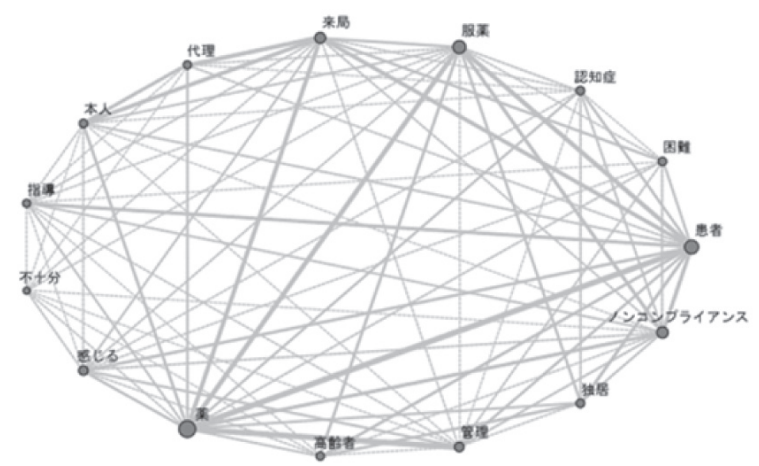

図 5 訪問指導の必要性に関するアンケート結果で の Web グラフ（1 リンク以上）

\section{2. テキストマイニングによる在宅医療への参加 に関する薬羭師の意識}

(1) 質問 8. 来局患者に対する在宅訪問薬剤管理 指導の必要性について

「薬局で対応をしている際に訪問指導を行う必 要性を感じた患者がいる」と回答した薬局が 181 （48.4\%）を占めた。さらに訪問指導が必要と考 える患者像について自由記載形式での回答を求 め, 143 名分のデー夕を用いてテキストマイニン グを行った. 抽出されたキーワードをカテゴリ化 した結果，131 名の記述内容を反映する 15 個の カテゴリが構築された（図 4)。カテゴリ間の関 係を極力カバーするために Web グラフで視覚化 し,リンク数 (カテゴリ間を結ぶ線) が全てのキー ワードを網羅する 1 以上のケースでカテゴリの相 互関連の強いものを列挙すると, (1)「患者一薬 服薬ーノンコンプライアンス」 (2)「代理－患者

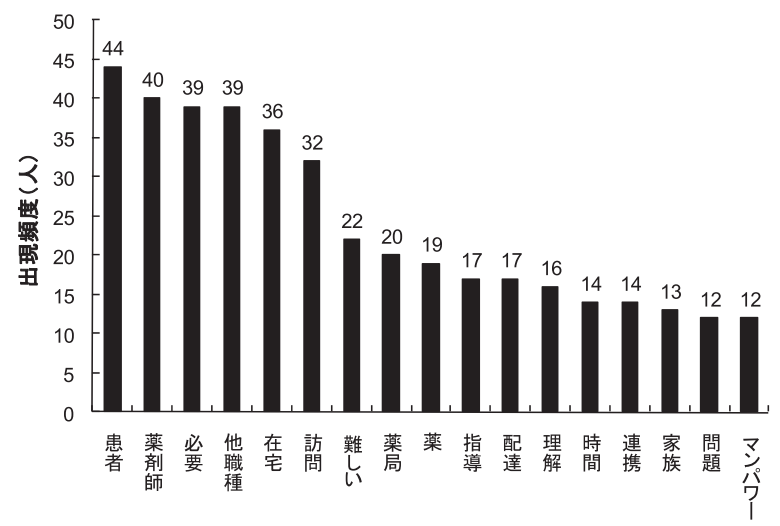

(頻度総数: 406)

図 6 在宅医療全般に関するアンケート結果での各 カテゴリの出現頻度

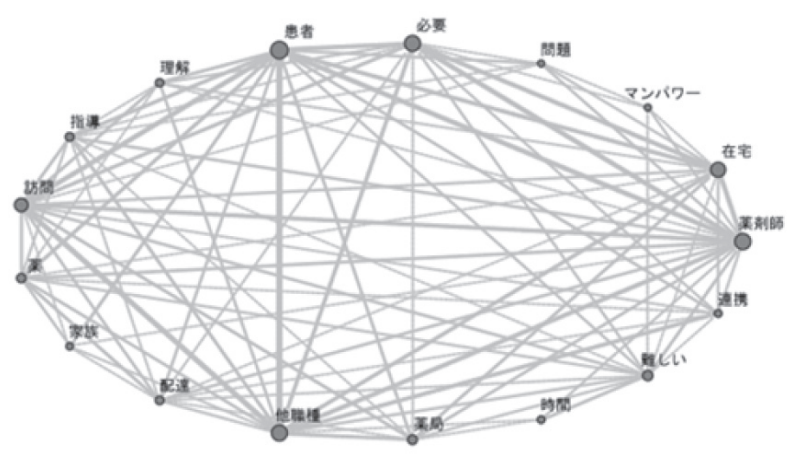

图 7 在宅医療全般に関するアンケート結果での Web グラフ（4 リンク以上） 
- 来局 - 困難」 (3)「独居 - 高齢者 - 薬 - 管理」 (4)「認知症 - 独居 - 薬 - 服薬」(5)「認知症 - 独 居－薬－管理」の関倸が示された（図 5).

(2) 質問 10.「在宅患者訪問薬剂管理指導」およ び「居宅療養管理指導」の実施に対する意見 106 名から得られた自由記載の内容を用いてテ キストマイニングを行った．抽出されたキーワー ドをカテゴリ化した結果, 95 名分の記述内容を 反映する 17 個のカテゴリが構築された（図 6). カテゴリ間の関係を Web グラフで視覚化したと ころ, リンク数が 4 以上のケースでカテゴリの相 互関連の強いものを列挙すると, (1)「在宅一薬剤 師 - 必要 - 患者」,「患者 - 必要 - 訪問 - 薬剤師」 (2)「患者 - 訪問 - 他職種 - 薬剤師」「薬剂師 - 他 職種 - 連携 - 必要」,「訪問 - 患者 - 必要 (理解) 一他職種」 (3)「マンパワー- 必要 (在宅) - 薬郕 師 - 難しい」, 「薬剤師 - 薬局 - 時間 - 難しい」 (4)「訪問 - 薬 - 家族 - 配達」,「訪問 - 薬 - 家族 (指 導)－配達」の関係が示された（図 7).

\section{考察}

常勤薬郕師数は平均 2.26 人で小人数であり, 在宅（居宅）での服薬指導実施が困難あるいは訪 問時間带が限定される保険薬局が多いことが示唆 された，そのような状況下でも，訪問指導の届出 数㧍よび訪問指導の指示があれば対応できると回 答した保険薬局は $75.4 \%$ を占めた。 しかし, 実際 に訪問指導を行っているのは $30.3 \%$ の保険薬局で あり，現状では訪問服薬指導を行っている保険薬 局の割合は少ないと思われる，そのため，訪問介 護員などの他職種が日々の薬剤管理や服薬介助を 行っているものと推定される ${ }^{3 \sim 4)}$. 一方, 日本薬 率師会の在宅医療に関する調査では，90\%以上の 介護施設への入居者が何らかの薬剤を服用し，そ の内重複投与など薬学上問題がある入居者の割合 が約 2 割で見られたと報告した（http://www. mhlw.go.jp/stf/shingi/2r9852000001jlr7-att/ 2r9852000001jlvh.pdf)。今回介護施設において薬 剤師が薬剤の服薬指導等にどの程度関与している か調査を行った，その結果, 処方薬の配達は約 3 割の保険薬局で行われ，薬剤師が服薬指導を行っ
ていたのはその内の $19.8 \%$ であったため, 介護施 設では薬郕師による服薬指導はほとんど行われて おらず，入院患者および来局患者に比較して介護 施設入所患者に対する服薬指導の実施率は少ない ことが明らかとなった。今後は在宅患者だけでな く, 介護施設入居者に対しても薬剂師が服薬指導 を行う必要があると思われる。

従来, 訪問薬剂管理指導を実施するにあたって の阻害要因として, 在宅療養支援の仕組みに対す る薬剤師の知識不足が指摘されている2). 具体的 には，在宅医療を行う際には，様々な届出等の申 請が必要であり，また他職種との連携が必要とさ れ, さらには薬学的管理を通して在宅患者に対す る薬片師による薬物療養支援への対応が求められ ている，在宅医療を行う際にはそれらの知識や対 応方法などを予め知っておくことが必要となるた め，在宅療養支援に関連した研修が必要である。 しかし, 今回の調查から, 実際に研修会等に参加 したのは $9.1 \%$ で，適切な研修会がないなどの理 由でほとんどの保険薬局薬剤師は実務研修会に参 加していない現状が見られた. しかしその一方で, 研修会等に参加した $76.1 \%$ の薬剂師はさらに研修 会に参加したい意向を持っていた.この現状から， 実際に在宅療養支援を行っている保険薬局では担 当薬片師が試行錯誤しながら訪問服薬指導業務や 他職種との連携を行っていると考えられる。その ため, 薬剤師が在宅医療に携わるモチベーション の維持や新たに取組むための環境を構築する必要 性が報告されている ${ }^{5)}$ ，そのためには，地域医療 における薬剂師による在宅医療を広める目的で在 宅関連研修会の開催が必要と考え, 我々は大学薬 学部による支援の一環として現在, 開局薬剤師を 対象とした在宅医療支援研修会および抗がん剤調 製を含む無菌調製とフィジカルアセスメントに関 する技能講習会を大学主催で行っている（図 8). その内容は, 在宅医療を行うにあたって必要な実 践的な知識を効率よく学べるものとした. 同研修 会では, 在宅医療未経験者を対象に行ったが, 今 回の開催では「在宅医療での実例に基づいた実践 的な知識が得られた」など研修会に参加して有益 であったとの意見をいただき，各研修会の平均満 足度（10段階評価）も 7.9 で一定の評価をいた 


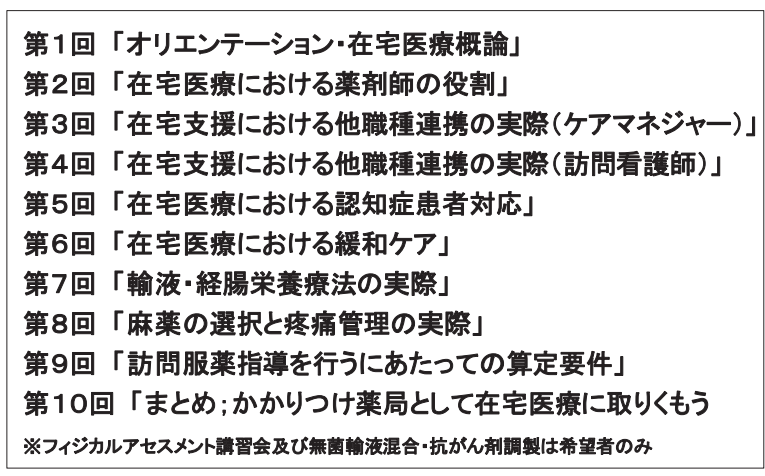

図 8 「薬剂師のための在宅医療支援研修会」プログ ラム

だいた。その結果，「在宅医療にかかわっていき たい」などの積極的な意見を得られた。詳細につ いては，その研修会を継続しながら薬局薬剤師の 在宅医療への参画促進に貢献するかの効果を調査 する予定である。

一方，退院時共同指導を行っている保険薬局は $3.7 \%$ ので, また, 今は行っていないが今後行 う計画を有する割合も $15.8 \%$ で少なかった。 その 理由として，「退院時間の調整が困難」の回答が 多く見られ，ほかに「病院との情報の共有化が困 難」や「患者から直接情報を入手する」などの否 定的な記述も見られた。退院時共同指導は保険薬 局薬剂師にとっては入院中の患者の詳細な情報を 関連職種から得て, 退院後の薬物治療を支援する ための貴重な場となり得るが, 病院・診療所など の処方也ん発行機関とは処方せんのみを介しての 関与であり，また実施地域における病院薬郕師と 薬局薬郕師との連携強化並びに体制整備, 人員確 保が大きな課題となっているとの報告 ${ }^{6)}$ もあり, 病院内で行われる退院時共同指導に参加困難な実 態が示された。しかし，一貫した医療を患者が受 ける必要性から, 病院薬剂師から退院時共同指導 に関する入院時の患者情報を発信することが求め られる。そのためには, 病院薬剤師と薬局薬剤師 とのさらなる連携の強化が必須である。併せて, 退院時共同指導の施設基準に薬剤師を明記するな どの法的整備や, 地域での連携システムを構築し, 情報収集・提供のためのツール作成などを行うが 必要であると思われる。

在宅医療への薬局薬剤師の介入は必要不可欠と
されているが, 在宅医療を行っている保険薬局が 少ない理由の 1 つとして, 在宅医療にかかわる他 職種との連携が十分にとれていないことが報告さ れている ${ }^{2)}$. 今回の調査でも, 「他職種連携を経 験した」と回答した保険薬局は約 $25 \%$ にどまっ ている。他職種との連携実施体制の不備が薬剂師 による在宅療養支援を阻害している大きな要因と なっている可能性が見られた。 また，先に示した 退院時共同指導での低い実施率の結果は, 薬局薬 剤師と病院薬剤師との連携の不備を示している. 退院時共同指導は, 患者中心の在宅医療を進めて いくうえで，患者情報収集の場のみならず，他職 種との連携を円滑にかつ効率的に行える場である. 薬剤師が来客患者の訪問指導を行う必要性につ いての自由回答を用いたテキストマイニングの結 果からは，服薬のコンプライアンスが不良ないし 服薬に問題があることが確認された患者, 患者本 人でなく代理者が来局した時, 独居の高齢者が薬 を管理している場合, そして認知症患者が薬を服 用ないし管理している場合には薬剤師の介入が必 要すなわち在宅での薬剤管理指導が必要であるこ とが示された。代表的な記載内容として，「服薬 コンプライアンス不良, 実際お薬を手に取って服 用しているところをお話しながらみてみたい患者 様がいる」,「1 人暮らしの高齢者の方で薬の管理 ができていない時」,「ご本人が来局できず，いつ も代理の方が来られていると具体的な服薬状況や 副作用の兆候のチェックなどが把握できないこと がある」そして「認知症のため, 服薬の真否を実 際に確かめたほうがよい場合がある」などの時に 薬剤師は在宅訪問を強く感じていることが伺え た。また，在宅医療全般についての自由回答を用 いたテキストマイニングの結果からは，患者宅へ の在宅訪問には薬剤師が必要であるとの薬剤師の 強い思いが感じられた。現状では, 患者や家族が 薬剤師の訪問を受け入れるメリットを享受できて いないため, 薬剤師の訪問に対する理解が進まず, 「薬の配達」にとどまっているケースが多いこと， また他職種から薬剂師の在宅訪問の意義が理解さ れていないなど薬剤師側の問題が明らかになっ た、また，別のリンクの組み合わせからは，在宅 医療を行うには患者や家族の理解とともに, 薬剤 
師自身が他職種と連携する必要性を感じていた。 一方，在宅訪問を行うための薬剤師のマンパワー の不足や訪問時間の不足を感じている薬剤師が多 いことが見られ，在宅医療実施の大きな阻害因子 となっている可能性が見られた。 これらテキスト マイニングにより得られた知見は，先に報告され てきた内容と共通点が見出されたが ${ }^{2)}$ ，質問 8 で は 131 名そして質問 10 では 95 名による自由記述 デー夕を体系的にまとめ, より一般化した形で整 理できたことに意義があると考えている.

本研究により, 保険薬局薬剂師は在宅医療の必 要性を感じつつも, 薬剤師人員不足, 他職種連携 の不安, 在宅研修会の不足など在宅医療を促進す る環境が十分に整っていない実態が示唆された。 また，介護施設を含めた薬剤師による訪問指導を 全く受けていない在宅患者層の存在が大きな課題 となっていた。これらの課題の解決策として, 他 職種連携の強化, 薬剂師業務の効率化, 退院時共 同指導の推進，コミュニケーション能力の改善を 含む在宅業務修得のプログラム化を産学連携で検 討することが重要であると考える。その場合, 薬 系大学・薬学部が地域医療への寄与の一環とし て, 地域薬剤師会と連携しながら地域の在宅医療 支援に学術面などで参画し寄与することが必須と 考えられる。

その結果, 病院薬剂師・薬局薬剤師・大学間連 携の下で，薬剤師が在宅医療に参加することは在 宅療養支援の質の向上を含む地域医療への貢献た けでなく, 薬剤師の職能のさらなる拡大に繋がり, 薬剤師が医療における位置づけがさらに高まるこ とも期待できる。 また, 今回のアンケート調査で 在宅療養を含む薬剂師による地域医療への参画・ 寄与の状況を薬学教育に活かし，卒業後薬学部生
が在宅医療に円滑に参画できるように薬学部教員 はそれらの教育にも積極的に取り入れていかなけ ればならないと考える。

\section{謝辞}

本研究でのアンケート調査にご協力をいただき ました大阪府下の 3 地域 (大阪北部 - 南東部 - 南 西部）の地区薬剤師会会員の諸先生に厚く感謝い たします。

\section{引用文献}

1）七海陽子, 恩田光子, 櫻井秀彦, 田中理恵, 坪田 賢一, 的場俊哉, 向井裕亮, 荒川行生, 早瀬幸俊, 在宅ケアにおける薬剤師業務に対するケアマ ネージャーの情報収集手段及び意識・要望に関 する調査研究, 薬学雑誌, 2011, 131, 843-851.

2）日本薬剤師会, 在宅療養推進アクションプラン, 日本薬剂師会雑誌, 2011, 63, 235-237.

3）富澤崇, 猿田祐子, 高松昭司, 林 和歌子, 藤代 成一, 中島新一郎, 在宅介護における高齢者の医 薬品適正使用の推進一パート 1 : 訪問介護員を 対象としたアンケート調査一, 医療薬学, 2007, 33, 755-761.

4）畑中典子, 伊藤貴文, 石幡真澄, 小島美里, 根本 英一, 大嶋 繁, 小林大介, 在宅患者のアドヒア ランスに及ぼす背景因子の解析一真の服用率と ヘルパーの推定する服用率の比較一, 薬学雑誌, 2009, 129, 727-734.

5）今村牧夫, 芝崎由美子, 岡崎宏美, 他地域の薬剤 師に対する緩和ケア教育の必要性と有用性, 日 本病院薬剤師会雑誌, 2010, 46, 963-968.

6）日本病院薬剤師会療養病床委員会, 退院時指導 業務に関する現状調査報告, 日本病院薬剤師会 雑誌, 2010, 46, 149-158. 